\title{
Review and Discussion on Standards for Shore-to-Ship Power Supply System
}

\author{
Juxiang HE, Xin LI, Hongsheng XU, Jinda ZHU, Pan DAI, Heli CHU \\ Technology Center \\ NARI Group Corporation \\ Nanjing, China \\ e-mail: hejuxiang@sgepri.sgcc.com.cn
}

\begin{abstract}
Shore-to-ship power supply system has become core technology dealing with shipping environmental pollution. However, the lack of systemic technical standards of it has brought great challenges. This paper proposes standards system for shore-to-ship power supply system, which based on analyzing the trend of international shore-to-ship power supply system technology and the existing problems of current standards. It is prospected that the standards will push the development of shore-to-ship power supply system continuously in the future.
\end{abstract}

Keywords-shore-to-ship power supply system;standardization; standard systems

\section{INTRODUCTION}

With the proposal of China "The Belt and Road" strategy and the development of economic globalization, shipping industry has got a period of vigorous development. Indeed, in order to meet the requirements of the normal operation of mechanical device, other faculties and their supply system working normally, the powerful fuel generators on shipboard must work continuously both at sea and in river. Even if ships are docked, they often use auxiliary engines to meet requirements such as refrigeration, lighting, emergency, communications, air conditioning and heating [1-5]. Both of shipping methods have produced substantially exhaust gas emissions and air pollution. According to International Maritime Organization (IMO), pollutant emissions from shipping keep rising, especially, sulfide and nitrogen oxide. A green, clean, electrified and low-carbonized port provides the necessary condition for global sustainable development.

Shore-to-ship power supply systems allow vessels to plug into an onshore power supply and shut down their auxiliary engines while berthed. The ship's power load is seamlessly transferred to the shore-side power supply without disrupting to onboard services. This substantially reduces fuel consumption, greenhouse gas emissions, noise and vibrations, which greatly improves the environment of port [6]. In 2014, California mandated that at least half of all the container ships run on shore-side electricity at berth. Moreover, the provision of shore power at EU ports will become a mandatory requirement by 2025 . At the same period, China have also introduced restrictions on ship pollution emissions and mandatory use of shore power supporting policies [1-6]. All of these have contributed to the use and development of shore-to-ship power supply system.

Nowadays, shore-to-ship power supply system has become focus technology to deal with shipping environmental pollution. With the promotion of national policies, the world's major ports are invested heavily to carry out research and development work on shore-to-ship power supply system and the effort is increasing by years. However, there are a number of challenges in high and low voltage shore connection systems. They need to be compatible between ship and shore connection equipment including plugs, socket-outlets and ships couplers, but there are no harmonized clear standards to regulate and test the quality of this kind of products. Many small and medium-sized ports use simple riveting methods to get power supply from shore because of lacking of standards, thus security problems are very serious. It is significant to solve the problem of shoreto-ship power supply system standards current ones are unbalanced, incomplete and disconnected.

Based on the analysis of present situation of shore-toship power supply system, and the domestic and foreign standards, this paper analyzes the development trend of international shore-to-ship power supply system technology, describes the existing problems of current standards, and proposes the standards system of shore-to-ship power supply system and making a feasible prospect of the its standardization.

\section{MAIN CONTENT}

\section{A. Shore-to-Ship Power Supply System}

As we know, shore-to-ship power supply system consists of Cold ironing, Onshore power supply, Alternative Maritime Power supply (AMP), etc. Usually, it includes shore power supply, converters, transformers and switchgear, protection equipment, control and communication systems, cable management system and sockets, indoor or outdoor packages, and so on. A typical shore-to-ship power supply system described in this paper is consisting of hardware components, and which is shown in Figure 1.

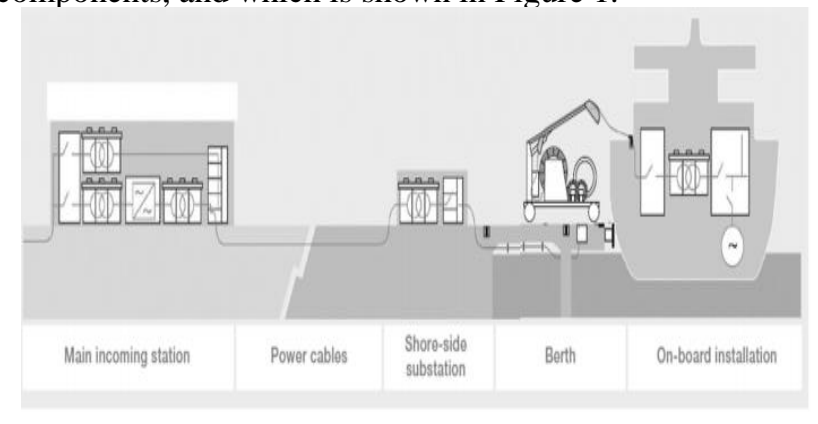

Figure 1. A typical described shore-to-ship power supply system. 
The applications and segments of shore-to-ship power supply system are presented in Table I.

TABLE I. THE APPLICATIONS AND SEGMENTS OF SHORE-TO-SHIP POWER SUPPLY SYSTEM

\begin{tabular}{|c|c|c|c|c|c|}
\hline & \multicolumn{5}{|c|}{ Vessel Type } \\
\hline $\begin{array}{c}\text { Characte } \\
\text { ristics }\end{array}$ & $\begin{array}{l}\text { RORO } \\
\text { /Ferry }\end{array}$ & $\begin{array}{c}\text { Containe } \\
\mathrm{r}\end{array}$ & Cruise & $\begin{array}{c}\text { LNG/ } \\
\text { Tanker } \\
\text { FSU/ } \\
\text { FPSO }\end{array}$ & $\begin{array}{c}\text { Shipyards/ } \\
\text { Navy }\end{array}$ \\
\hline Voltage & $\begin{array}{c}11 \mathrm{kV} \\
\text { or low } \\
\text { voltag } \\
\mathrm{e}\end{array}$ & $6.6 \mathrm{kV}$ & $\begin{array}{c}6.6 \& 1 \\
1 \mathrm{kV}\end{array}$ & $6.6 \mathrm{kV}$ & $\begin{array}{c}6.6 \mathrm{kV}, 11 \mathrm{k} \\
\mathrm{V} \text { or low } \\
\text { voltage }\end{array}$ \\
\hline $\begin{array}{c}\text { Max } \\
\text { Power } \\
\text { consumpt } \\
\text { ion }\end{array}$ & $\begin{array}{c}6.5 \mathrm{MV} \\
\mathrm{A}\end{array}$ & 7.5MVA & $\begin{array}{l}16 / 20 \\
\text { MVA }\end{array}$ & $\begin{array}{l}\text { Appro } \\
\text { X } 10 \\
\text { MVA }\end{array}$ & $\begin{array}{c}\text { Case by } \\
\text { Case }\end{array}$ \\
\hline $\begin{array}{c}\text { Frequenc } \\
\mathrm{y}\end{array}$ & $\begin{array}{c}60 \& 50 \\
\mathrm{~Hz}\end{array}$ & $\begin{array}{c}60 \\
\text { mainly }\end{array}$ & $\begin{array}{c}60 \\
\text { mainly }\end{array}$ & $60 \mathrm{~Hz}$ & $50 \& 60 \mathrm{~Hz}$ \\
\hline $\begin{array}{c}\text { Plugs/Ca } \\
\text { bles(per } \\
\text { connectio } \\
\text { n) }\end{array}$ & 1 & 2 & $4+1$ & $2 / 3$ & $\begin{array}{c}\text { Case by } \\
\text { Case }\end{array}$ \\
\hline $\begin{array}{c}\text { Transfor } \\
\text { mer }\end{array}$ & $\begin{array}{c}\text { onboar } \\
\mathrm{d}\end{array}$ & onshore & $\begin{array}{c}\text { onshor } \\
\mathrm{e}\end{array}$ & $\begin{array}{l}\text { onsho } \\
\text { re }\end{array}$ & $\begin{array}{c}\text { Case by } \\
\text { Case }\end{array}$ \\
\hline Layout & $\begin{array}{c}\text { Not } \\
\text { critical }\end{array}$ & critical & critical & $\begin{array}{c}\text { critica } \\
1\end{array}$ & Not critical \\
\hline $\begin{array}{l}\text { Load } \\
\text { profile }\end{array}$ & $\begin{array}{c}\text { Partial } \\
\text { ly } \\
\text { control } \\
\text { led }\end{array}$ & $\begin{array}{c}\text { Partially } \\
\text { controlle } \\
\text { d }\end{array}$ & $\begin{array}{c}\text { Flat } \\
\text { profile }\end{array}$ & $\begin{array}{l}\text { Not } \\
\text { contro } \\
\text { lled }\end{array}$ & $\begin{array}{c}\text { Case by } \\
\text { Case }\end{array}$ \\
\hline $\begin{array}{c}\text { Protect } \\
\text { selectivit } \\
y\end{array}$ & critical & $\begin{array}{c}\text { Not } \\
\text { critical } \\
\text { (If } \\
\mathrm{P}=7.5 \mathrm{M} \\
\text { VA) }\end{array}$ & critical & $\begin{array}{c}\text { Case } \\
\text { by } \\
\text { Case }\end{array}$ & $\begin{array}{c}\text { Case by } \\
\text { Case }\end{array}$ \\
\hline $\begin{array}{c}\text { Cable } \\
\text { managem } \\
\text { ent } \\
\text { system }\end{array}$ & $\begin{array}{l}\text { Mid } \\
\text { cost }\end{array}$ & Low cost & $\begin{array}{l}\text { High } \\
\text { cost }\end{array}$ & $\begin{array}{l}\text { Mid } \\
\text { cost }\end{array}$ & $\begin{array}{c}\text { Case by } \\
\text { Case }\end{array}$ \\
\hline
\end{tabular}

According to the Table I, because of the differences among power supply's voltage, frequency, max power consumption, and ship's types, voltage, frequency in different areas, there are different technology implementation plans to supply the ship with electrical power from shore, such as low voltage or high voltage to realize the shore power supply. Another difference is that sometimes shore-to-ship power system needs to increase the frequency conversion and voltage variable equipment, while sometimes not. In the future, wireless charging may be achieved to connect the ship and shore without the shipshore connecting cable and cable drum.

\section{B. International Technical Standards}

In 2005, Port of Long Beach distributed a preliminary standard design for shore-side power supply at their port. It is expected that the wharf outlet will be $6.6 \mathrm{kV}, 3$-phase, and $60 \mathrm{~Hz}$ with a grounding conductor, and a design load of 7.5 MVA for each ship. As shore-to-ship power supply systems have grown in interest, three standard groups ISO, IEC and IEEE, began to carry out the construction of standards as follows.
TABLE II. INTERNATIONAL TECHNICAL STANDARDS OF SHORE-TOSHIP POWER SUPPLY SYSTEM[7-12]

\begin{tabular}{|c|c|c|c|}
\hline Number & Standard Name & Scope & Date \\
\hline $\begin{array}{l}\text { ISO/WD } \\
29501\end{array}$ & $\begin{array}{ll}\text { On shore } & \text { power } \\
\text { supply, } & \text { "Cold } \\
\text { Ironing", } & \end{array}$ & I & $\begin{array}{l}\text { 2007-04- } \\
01\end{array}$ \\
\hline $\begin{array}{c}\text { ISO/IEC/PAS } \\
60092-510- \\
2009\end{array}$ & $\begin{array}{l}\text { Electrical installations } \\
\text { in ships - Part } \\
510 ; \text { Special features - } \\
\text { High Voltage Shore } \\
\text { Connection Systems }\end{array}$ & $\begin{array}{l}\text { specification, } \\
\text { installation and } \\
\text { testing of } \\
\text { HVSC- } \\
\text { Systems } \\
\end{array}$ & $\begin{array}{c}\text { 2009-04- } \\
01\end{array}$ \\
\hline $\begin{array}{c}\text { IEC 62613-1- } \\
2011\end{array}$ & $\begin{array}{l}\text { Plugs, socket-outlets } \\
\text { and ship couplers for } \\
\text { high-voltage shore } \\
\text { connection systems } \\
\text { (HVSC-Systems) -- } \\
\text { Part 1: General } \\
\text { requirements }\end{array}$ & $\begin{array}{l}\text { applies to } \\
\text { accessories } \\
\text { with three } \\
\text { phases(3 poles } \\
\text { and earth) with } \\
\text { up to three } \\
\text { pilot contacts, } \\
\text { one single } \\
\text { pole(Neutral) }\end{array}$ & $\begin{array}{l}\text { 2011-06- } \\
01\end{array}$ \\
\hline $\begin{array}{c}\text { IEC 62613-2- } \\
2016\end{array}$ & $\begin{array}{l}\text { Plugs, socket-outlets } \\
\text { and ship couplers for } \\
\text { high-voltage shore } \\
\text { connection systems } \\
\text { (HVSC-systems) - } \\
\text { Part 2: Dimensional } \\
\text { compatibility and } \\
\text { interchangeability } \\
\text { requirements for } \\
\text { accessories to be used } \\
\text { by various types of } \\
\text { ships }\end{array}$ & $\begin{array}{l}\text { applies to } \\
\text { accessories up } \\
\text { to } 12 \mathrm{kV}, 500 \\
\text { A, } 50 / 60 \mathrm{~Hz} \\
\text { and with up to } \\
\text { seven } \\
\text { pilot/auxiliary } \\
\text { contacts }\end{array}$ & $\begin{array}{c}\text { 2016-11- } \\
30\end{array}$ \\
\hline $\begin{array}{l}\text { IEC/ISO/IEEE } \\
80005-1-2012\end{array}$ & \begin{tabular}{lr}
\multicolumn{2}{l}{ Utility connections in } \\
port -- Part $1:$ High \\
Voltage & Shore \\
Connection & (HVSC) \\
Systems -- & General \\
requirements & \\
\end{tabular} & $\begin{array}{l}\text { design, } \\
\text { installation and } \\
\text { testing } \\
\text { HVSC- } \\
\text { systems and } \\
\text { addresses } \\
\end{array}$ & $\begin{array}{l}\text { 2012-07- } \\
01\end{array}$ \\
\hline $\begin{array}{c}\text { IEC/IEEE } \\
80005-2-2016\end{array}$ & $\begin{array}{l}\text { Utility connections in } \\
\text { port - Part 2: High } \\
\text { and low voltage shore } \\
\text { connection systems - } \\
\text { Data communication } \\
\text { for monitoring and } \\
\text { control }\end{array}$ & $\begin{array}{l}\text { specifies the } \\
\text { interface } \\
\text { descriptions, } \\
\text { addresses and } \\
\text { data type }\end{array}$ & $\begin{array}{l}\text { 2016-06- } \\
01\end{array}$ \\
\hline $\begin{array}{c}\text { IEC/PAS } \\
80005-3-2014\end{array}$ & \begin{tabular}{lr}
\multicolumn{2}{l}{ Utility connections in } \\
port - Part & 3: Low \\
Voltage & Shore \\
Connection & (LVSC) \\
Systems - & General \\
requirements &
\end{tabular} & $\begin{array}{l}\text { design, } \\
\text { installation and } \\
\text { testing of } \\
\text { LVSC-systems } \\
\text { and addresses }\end{array}$ & $\begin{array}{l}\text { 2014-08- } \\
01\end{array}$ \\
\hline
\end{tabular}

\section{Domestic Technical Standards}

Since the 1990s, our institutions and enterprises have developed a series of standards based on the application and technique feature of shore-to-ship power supply system in China, including national standard, industry standards, and enterprise standards, which provides technical reference and experience for the application of shore-to-ship power supply technology in our country.

At the enterprise standard level, in 2015, the State Grid Corporation organized the domestic power industry enterprises and institutions to complete 14 enterprise standards, including terms and definitions, construction 
technical conditions, equipment technical conditions, operation and maintenance technology of shore-to-ship power supply system, which describe the general requirements of design, energy metering, high voltage power supply, shore connection and interface equipment, testing, monitoring systems and other aspects. The implementation of the State Grid Corporation's enterprise standards has played a leading role in the field of China's shore-to-ship power supply system, and further promoted the application of shore-to-ship power supply technology and the development of engineering practice.

TABLE III. NATIONAL STANDARDS OF SHORE-TO-SHIP POWER SUPPLY SYSTEM[13-15]

\begin{tabular}{|c|c|c|c|}
\hline Number & Standard Name & Scope & Date \\
\hline $\begin{array}{l}\text { GBT 25316- } \\
\quad 2010\end{array}$ & $\begin{array}{l}\text { Static shore power } \\
\text { supply (SPS) system }\end{array}$ & $\begin{array}{l}\text { specification, } \\
\text { installation } \\
\text { and testing of } \\
\text { SPS system }\end{array}$ & $\begin{array}{l}\text { 2011-05- } \\
01\end{array}$ \\
\hline $\begin{array}{c}\text { GBT } \\
30845.1-2014\end{array}$ & $\begin{array}{l}\text { Plugs, socket-outlets } \\
\text { and ship couplers for } \\
\text { high-voltage shore } \\
\text { connection systems } \\
\text { (HVSC-Systems) -- } \\
\text { Part 1: General } \\
\text { requirements }\end{array}$ & $\begin{array}{l}\text { IEC 62613- } \\
1: 2011, \\
\text { MOD }\end{array}$ & $\begin{array}{l}\text { 2015-01- } \\
22\end{array}$ \\
\hline $\begin{array}{c}\text { GBT } \\
30845.2-2014\end{array}$ & $\begin{array}{l}\text { Plugs, socket-outlets } \\
\text { and ship couplers for } \\
\text { high-voltage shore } \\
\text { connection systems } \\
\text { (HVSC-systems) - } \\
\text { Part 2: Dimensional } \\
\text { compatibility and } \\
\text { interchangeability } \\
\text { requirements for } \\
\text { accessories to be used } \\
\text { by various types of } \\
\text { ships }\end{array}$ & $\begin{array}{l}\text { IEC 62613- } \\
2: 2011, \\
\text { MOD } \\
\text { Note: } \\
\text { IEC } 62613- \\
2: 2016 \text { has } \\
\text { replaced IEC } \\
62613-2: 2011\end{array}$ & $\begin{array}{l}\text { 2015-01- } \\
22\end{array}$ \\
\hline
\end{tabular}

\section{DISCUSSION OF STANDARDS OF SHORE-TO-SHIP POWER SUPPLY SYSTEM}

\section{A. Similar Items}

According to the Table II IV, some interesting details have been found between international and domestic technical standards of shore-to-ship power supply system. International and domestic technical standards both describe shore distribution systems, shore-to-ship connection and interface equipment, transformers/reactors, semiconductor/rotating convertors, ship distribution systems, control, monitoring, interlocking and power management systems. All standards are involved in design, installation and testing of high and low voltage shore connection systems, and the dimensional compatibility and interchangeability of plugs, socket-outlets and ship couplers for high-voltage shore connection systems. It seems that the research and establishment of domestic technical standards usually follow the international technical standards' footsteps.

\section{B. Differences Items}

Except for some similar items on international and domestic technical standards, some differences also in these standards. First of all, IEC/IEEE 80005-2-2016 describes the data interfaces of shore and ships as well as step by step procedures for low and high voltage shore connection systems communication for non-emergency functions, where required. Furthermore, this standard specifies the interface descriptions, addresses and data type, communication requirements on cruise ships also included. However, there is no individual description in domestic technical standards. The second difference is that domestic technical standards focused more on product standards and operating procedure. In the opposite side, international technical standards have focused more on technical requirements of component. Finally some differences appeared in the systematic design of standard. For example, GBT 25316-2010 is an individual standard

TABLE IV. TRAFFIC AND SHIP INDUSTRY STANDARDS OF SHORE-TOSHIP POWER SUPPLY SYSTEM[16-23]

\begin{tabular}{|c|c|c|c|}
\hline Number & Standard Name & Scope & Date \\
\hline $\begin{array}{l}\text { JTT 347- } \\
1995\end{array}$ & $\begin{array}{l}\text { Technical } \\
\text { requirements of } \\
\text { interface useing } \\
\text { land power source } \\
\text { for steel vessels }\end{array}$ & $\begin{array}{l}\text { technical } \\
\text { requirements of } \\
\text { shore power } \\
\text { supply }\end{array}$ & $\begin{array}{c}\text { 1996-06- } \\
01\end{array}$ \\
\hline $\begin{array}{l}\text { JTS 155- } \\
2012\end{array}$ & $\begin{array}{l}\text { Technical Code of } \\
\text { Shore-to-ship } \\
\text { Power Supply } \\
\text { System }\end{array}$ & $\begin{array}{l}\text { construction } \\
\text { technical } \\
\text { requirements of } \\
\text { shore-to-ship } \\
\text { power supply } \\
\text { system }\end{array}$ & $\begin{array}{l}\text { 2012-08- } \\
01\end{array}$ \\
\hline $\begin{array}{c}\text { JTT 814.1- } \\
2012\end{array}$ & $\begin{array}{l}\text { Shore-to-ship } \\
\text { power supply } \\
\text { system technical } \\
\text { conditions-Part } \\
1: \text { High voltage } \\
\end{array}$ & $\begin{array}{l}\text { testing, technical } \\
\text { requirements of } \\
\text { high voltage shore- } \\
\text { to-ship power } \\
\text { supply system }\end{array}$ & $\begin{array}{l}\text { 2012-10- } \\
01\end{array}$ \\
\hline $\begin{array}{c}\text { JTT 814.2- } \\
2012\end{array}$ & $\begin{array}{l}\text { Shore-to-ship } \\
\text { power supply } \\
\text { system technical } \\
\text { conditions-Part } \\
\text { 2:Low voltage }\end{array}$ & $\begin{array}{l}\text { testing, technical } \\
\text { requirements of } \\
\text { low voltage shore- } \\
\text { to-ship power } \\
\text { supply system }\end{array}$ & $\begin{array}{l}\text { 2012-10- } \\
01\end{array}$ \\
\hline $\begin{array}{c}\text { JTT 815.1- } \\
2012\end{array}$ & $\begin{array}{l}\text { Shore-to-ship } \\
\text { power supply } \\
\text { system operating } \\
\text { procedure-Part } \\
\text { 1:High voltage }\end{array}$ & $\begin{array}{l}\text { preparation, } \\
\text { connection, power } \\
\text { supply operating } \\
\text { technical } \\
\text { requirements of } \\
\text { high voltage shore- } \\
\text { to-ship power } \\
\text { supply system }\end{array}$ & $\begin{array}{l}\text { 2012-10- } \\
01\end{array}$ \\
\hline $\begin{array}{c}\text { JTT 815.2- } \\
2012\end{array}$ & $\begin{array}{l}\text { Shore-to-ship } \\
\text { power supply } \\
\text { system operating } \\
\text { procedure-Part } \\
\text { 2:Low voltage }\end{array}$ & $\begin{array}{l}\text { preparation, } \\
\text { connection, power } \\
\text { supply operating } \\
\text { technical } \\
\text { requirements of } \\
\text { low voltage shore- } \\
\text { to-ship power } \\
\text { supply system }\end{array}$ & $\begin{array}{l}\text { 2012-10- } \\
01\end{array}$ \\
\hline $\begin{array}{c}\text { CBT 4406- } \\
2014\end{array}$ & $\begin{array}{l}\text { Shore power } \\
\text { connection box }\end{array}$ & $\begin{array}{l}\text { Classification, } \\
\text { marking, testing of } \\
\text { Shore power } \\
\text { connection box }\end{array}$ & $\begin{array}{l}\text { 2014-10- } \\
01\end{array}$ \\
\hline $\begin{array}{c}\text { CBT 4372- } \\
2014\end{array}$ & $\begin{array}{l}\text { Small crafts Shore } \\
\text { power systems }\end{array}$ & $\begin{array}{l}\text { marking, testing of } \\
\text { Small crafts shore } \\
\text { power systems }\end{array}$ & $\begin{array}{l}\text { 2014-10- } \\
01\end{array}$ \\
\hline
\end{tabular}

\section{Results}

Shore-to-ship power supply system is a complex system, including power electronics technology, frequency 
conversion technology, monitoring technology, communication technology, metering technology and so on. Meanwhile, due to the shore-to-ship power supply system playing the role of slowing the rate of climate changing, so its standardization will become more and more important. Even the international and domestic standards have different focuses, these standards of shore-to-ship power supply system cover safety, compatibility between shore connection and ship equipment, a small amount of testing and other aspects. There are also lack of professional standards of verifying and testing, energy metering, accessing to power grid, operating and maintaining and so on. It's necessary to design from the top, establish technical standard system quickly.

\section{TECHNICAL STANDARD SYSTEM FOR SHORE-TO-SHIP POWER SUPPLY SYSTEM}

Recently, in view of the development of shore power and the existing standards are not matched, the State Grid Corporation and NARI Group Corporation began to set up "energy industry shore-to-ship power supply facilities technical committee for standardization". Nowadays, the committee is at the approved stage of establishment. Meanwhile, they propose technical standard system from the top design, including the basic part of shore-to-ship power supply system, on-shore power supply system, connection system between ship and shore, on-ship receiving system, shore-to-ship power supply system and power grid, construction and operation.

The establishment of technical standard system mainly carried out two aspects of the work. First of all, according to the level of the standard, the size of the common technology and the scope of the standard, standards are categorized vertically, with the shore system, structural components, electrical equipment, core technology all included. Secondly, according to different industries, professional, categories or different technical systems in the industry chain, standards are classified horizontally, including electricity, communications, control, ships and other different categories.

It is possible to effectively promote the promotion and application of shore-to-ship power supply system through building standard system, and improve the overall technical level of shore-to-ship power supply system and construction quality, and further guide sustainable development of China's shore-to-ship power supply industry.

\section{CONCLUSION}

While using shore-to-ship power supply system has environmental and economic benefits, the lack of systemic technical standards bring great challenges. Three problems are solved which is about shore-to-ship power supply standards in this article. Firstly, the development trend of international shore-to-ship power supply system technology is analyzed. Secondly, the domestic and foreign standards of shore-to-ship power supply system are refreshed, and the existing problems of current standards are described. Finally, the new standards system of shore-to-ship power supply system is proposed. The new standard system will realize the unification of shore-to-ship power supply technology, and also propose a new direction of the shore-to-ship power supply system. With the further development of economy and technology and the continuous improvement of the standards system, the shore-to-ship power supply system will bring a new leap.

\section{ACKNOWLEDGMENT}

Thanks to Mr. Lang Gao and Ms Yun Wu for their suggestion. Thanks to my colleagues in NARI Group Corporation.

\section{REFERENCES}

[1] PED Paul, PB Chavdarian, "A closer look at the grounding of shoreto-ship power supply system," Industrial \& Commercial Power Systems Technical Conference, Calgary, pp 1-7, May 3-7, 2009.

[2] A Vicenzutti, F Tosato, G Sulligoi, G Lipardi and L Piva, "High voltage ship-to-shore connection for electric power supply support in landing operations: An analysis," Electric Ship Technologies Symposium, Alexandria, pp 364-369, June 21-24, $2015 .$.

[3] D Paul, V Haddadian, "Transient Overvoltage Protection of Shore-toShip Power Supply System," IEEE Transactions on Industry Applications, vol. 47, pp.1193-1200, 2010.

[4] D Paul, V Haddian, "Shore-To-Ship Power Supply System for a Cruise Ship" Industry Applications Society Annual Meeting, Houston, pp 1-7 Oct. 2009.

[5] R Strzelecki, P Mysiak, T Sak, "Solutions of inverter systems in Shore-to-Ship Power supply systems," International Conference on Compatibility and Power Electronics, Costa da Caparica, pp 454-461, June 24-26, 2015.

[6] R Yang, W Zhang, R Fan and Q Gu, "Standard Technical Research of Shore-to-Ship Power Supply System," Advanced Materials Research, vol. 998, pp. 549-552, 2014.

[7] ISO/IEC/PAS 60092-510, "Electrical installations in ships-Part 510: Special features-High Voltage Shore Connection Systems," ISO/IEC committee, 2009.

[8] IEC 62613-1, "Plugs, socket-outlets and ship couplers for highvoltage shore connection systems (HVSC-Systems)-Part 1: General requirements," IEC committee, 2011.

[9] IEC 62613-2, "Plugs, socket-outlets and ship couplers for highvoltage shore connection systems (HVSC-systems)-Part 2: Dimensional compatibility and interchangeability requirements for accessories to be used by various types of ships", IEC committee, 2016.

[10] IEC/ISO/IEEE 80005-1, "Utility connections in port -- Part 1: High Voltage Shore Con-nection (HVSC) Systems-General requirements", IEC/ISO/IEEE committee, 2012.

[11] IEC/IEEE 80005-2, "Utility connections in port - Part 2: High and low voltage shore connection systems - Data communication for monitoring and control", IEC/IEEE committee, 2016.

[12] IEC/PAS 80005-3, "Utility connections in port - Part 3: Low Voltage Shore Con-nection (LVSC) Sys-tems - General re-quirements", IEC committee, 2014

[13] GBT 25316-2010, "Static shore power supply (SPS) system,’2014.

[14] GBT 30845.1-2014, "Plugs, socket-outlets and ship couplers for highvoltage shore connection systems (HVSC-Systems) -- Part 1: General requirements",2015.

[15] GBT 30845.2-2014, "Plugs, socket-outlets and ship couplers for highvoltage shore connection systems (HVSC-systems) - Part 2 Dimensional compatibility and interchangeability requirements for accessories to be used by various types of ships",2015.

[16] JTT 347-1995, "Technical requirements of interface useing land power source for steel vessels,"1996.

[17] JTS 155-2012, “Technical Code of Shore-to-ship Power Supply System,"2012. 
[18] JTT 814.1-2012, "Shore-to-ship power supply system technical conditions-Part 1:High voltage,"2012.

[19] JTT 814.2-2012, "Shore-to-ship power supply system technical conditions-Part 2:Low voltage,"2012.

[20] JTT 815.1-2012, "Shore-to-ship power supply system operating procedure-Part 1:High voltage,"2012.
[21] JTT 815.2-2012, "Shore-to-ship power supply system operating procedure-Part 2:Low voltage,"2012.

[22] CBT 4406-2014, "Shore power connection box,"2014.

[23] CBT 4372-2014, "Small crafts Shore power systems,"2014. 